\title{
STRATEGI PENDEKATAN SUPPLY CHAIN MANAGEMENT PADA PROSES PRODUKSI DAN SALURAN DISTRIBUSI TERHADAP AGROINDUSTRI MANGGA (Mangifera indica) DI KABUPATEN PROBOLINGGO
}

\author{
Deny Utomo
}

\begin{abstract}
Abstrak
Supply chain management merupakan manajemen rantai pasokan atau manajemen organisasi yang saling berkaitan dan saling berintegrasi satu sama lain baik dengan konsumen maupun pemasok dalam suatu proses untuk menghasilkan nilai produk dan jasa bagi konsumen. Metode penelitian ini menggunakan empat metode, antara lain ; 1) Structural Equation Model (SEM) untuk menguji ketepatan model hipotetik secara empirik yang telah dikembangkan melalui justifikasi teoritis dan hubungan antar variabel yang dibangun dalam model, 2) model kelembagaan Agroindustri mangga Arumanis di Kabupaten Probolinggo dengan metode Interpretative Structural Model (ISM) yang dikembangkan melalui justifikasi teoritis dan keterlibatan beberapa lembaga baik pemerintah maupun swasta, 3) model analisis harga jual optimal mangga Arumanis Grade A, B, C di petani, pemasok dan eksportir dimasing-masing kecamatan (Besuk, Krejengan, Pajarakan) dengan metode Goal Programming (GP), dan 4) model transportasi dengan mencari total biaya minimum transportasi mangga Arumanis Grade A, B, C dimasing-masing kecamatan (Besuk, Krejengan, Pajarakan) dengan Method Vogel's Approximation (VAM).

Hasil penelitian menunjukkan bahwa, 1) faktor keberhasilan supply chain management berpengaruh signifikan paling besar terhadap proses produksi dan saluran distribusi mangga Arumanis, 2) proses produksi berpengaruh signifikan terhadap saluran distribusi dan agroindustri mangga Arumanis segar, 3) Saluran distribusi berpengaruh signifikan terhadap agroindustri mangga Arumanis segar, 4) Agroindustri mangga Arumanis segar berpengaruh signifikan terhadap agroindustri mangga Arumanis olahan, 5) Elemen kunci kelembagaan adalah Disperindag, 6) Harga jual maksimal mangga Arumanis Grade A di petani Rp. 15.376,-/kg, pemasok Rp. 28.269,-/kg, dan eksportir Rp. 39.201,-/kg. Sedangkan harga jual maksimal mangga Arumanis Grade B di petani Rp. 5.916,-/kg, pemasok Rp. 11.716,-/kg, dan eksportir Rp. 32.083,-/kg. Harga jual maksimal mangga Arumanis Grade C di petani Rp. 2.386,-/kg dan pemasok Rp..447,-/kg. 7) Total biaya minimum transportasi mangga Arumanis Grade A sebesar Rp. 896.489,-/ton, Grade B sebesar Rp. 710.625,-/ton, dan Grade C sebesar Rp. $509.000,-/$ ton.
\end{abstract}




\section{PENDAHULUAN}

\section{Latar Belakang}

Produksi tanaman mangga di Kabupaten Probolinggo pada tahun 2008 mengalami penurunan yaitu 99.621 ton, sedangkan tahun 2007 sebesar 101.585 ton. Luas areal panen mangga juga mengalami penurunan pada tahun 2008 sebesar 987.164 pohon, yang sebelumnya pada tahun 2007 sebesar 1.224.134 pohon (Disperta, 2009). Hal ini disebabkan karena rendahnya penguasaan teknologi oleh petani baik dari aspek pembibitan seperti produksi bibit/benih buah-buahan lokal dari segi kualitas relatif rendah dan segi kuantitas relatif terbatas, yang disebabkan oleh proses produksi banyak dilakukan oleh penangkar benih yang tidak profesional, cara panen (waktu panen dan cara panen) dan penanganan pasca panen yang tidak memperhatikan SOP dari dinas pertanian, kurangnya persediaan, pendistribusian, keterbatasan modal (pengajuan kredit yang sulit yang menyertakan jaminan dan besarnya bunga kredit) dan penanganan pasca panen. Sementara untuk ekspor ke Singapura juga menemui hambatan, karena saat ini mangga asal Probolinggo harus bersaing ketat dengan mangga dari Thailand (Deptan, 2009).

Supriatna (2005) menyatakan bahwa upaya meningkatkan daya saing pemasaran, baik di pasar dalam negeri maupun pasar internasional, tidak ada jalan lain bagi petani mangga Indonesia untuk bekerja keras, menyediakan produk melimpah dengan mutu tinggi dan diproduksi dengan biaya efisien, salah satunya dengan menggunakan strategi pendekatan Supply Chain Management (SCM). Pendekatan Supply Chain Management (SCM) atau Pengelolaan Rantai Pasokan dilakukan agar peningkatan daya saing itu tidak semata dilakukan melalui perbaikan produktivitas dan kualitas produk, tetapi juga melalui pengemasan, pemberian merk, efisiensi, transportasi, informasi, penguatan kelembagaan dan penciptaan inovasi secara kontinyu dan sistematik (Deptan, 2009).

SCM merupakan siklus lengkap produksi, mulai dari kegiatan pengelolaan di setiap mata rantai aktifitas produksi sampai siap untuk digunakan oleh pemakai. Pendekatan SCM pada produk hortikultura didasarkan pada; (a) Proses budidaya untuk menghasilkan produk (hortikultura), (b) Mentransformasikan bahan mentah (penanganan panen dan pasca panen), dan (c) Pengiriman produk ke konsumen melalui sistem distribusi. Untuk menjamin keberhasilan penerapan Supply Chain Management (SCM) atau Manajemen Pengelolaan Rantai Pasokan perlu memahami faktor-faktor pendukung keberhasilan antara lain : kebijakan, sumber daya manusia, prasarana, sarana, teknologi, kelembagaan, modal/ pembiayaan, sistem informasi, sosial budaya dan lingkungan lain (Saptana dkk., 2006). 
Poerwanto

(2009)

menyatakan di dalam SCM produk hortikultura khususnya kriteria mutu buah mangga memegang peranan yang sangat penting, karena faktor tersebut akan sangat berpengaruh terhadap persediaan dan kuantitas pendistribusian. Setyabudi $d k k$, (2007) menyatakan kehilangan dan kerusakan pascapanen buah-buahan, dari tingkat pedagang pengumpul hingga pedagang pengecer, diperkirakan mencapai 30\%. Hal ini mengisyaratkan potensi dan peluang investasi yang menjanjikan di bidang usaha penanganan pascapanen, penyelamatan hasil panen, dan industri pengolahannya.

Keberadaan SCM dalam pengembangan Agroindustri sangatlah diperlukan, karena memegang peranan yang sangat penting terhadap penentuan harga jual yang diterima konsumen. Mutu dan biaya transportasi merupakan hal yang paling mendasar dalam menentukan harga jual (Batt, 2004). Model agroindustri SCM mangga, meliputi penguasaan teknologi pengolahan sejak proses penanganan, sebelum hingga sesudah pengolahan. Penanganan sebelum pengolahan menyangkut sortasi, pencucian, pengupasan, dan lain-lain. Sedangkan, penanganan sesudah pengolahan menyangkut penyimpanan, pengemasan, dan distribusi pada standar mutu tertentu. Selanjutnya adalah manajemen bahan baku menyangkut penyediaan bahan baku yang kontinyu, harga stabil, dan mampu bersaing dengan bahan baku impor. Disamping model agroindustri dan manajemen bahan baku, kelembagaan yang ada juga harus mendapatkan dukungan pemerintah daerah, dimana agroindustri tersebut ditempatkan (Setyabudi $d k k$., 2007).

Di Cina, pemerintah mempunyai peranan yang sangat penting dalam angroidustrialisasi, khususnya merencanakan dan menerapkan supply-chain mitra untuk mengkoordinir fungsi persediaan dari produksi dan distribusi sesuai dengan kondisi pasar (Wei and Yangrong, 2004). Sedangkan di Thailand ada 2 kegiatan yang dilakukan untuk mengembangkan agroindustri SCM melalui, 1) pendirikan pusat pananganan pasca panen didaerah provinsi Ratchaburi dengan menampung semua produk mangga segar di tempat ini, untuk di kontrol kualitas dan keamanan produknya sebelum di jual di pasar domestik maupun eksport, 2) pendirian pusat pengemasan di Bangkok Air Port, semua produk yang telah lulus uji di pusat penanganan pasca panen dengan kualitas eksport di lakukan proses grading, sortasi, pencucian dan pengemasan di pusat pengemasan ini sebelum di eksport. Hal ini dilakukan untuk menjaga kualitas dan meminimalkan biaya distribusi untuk mendapatkan harga jual yang maksimal (FAO,2007).

Berdasarkan uraian dan permasalahan di atas perlu dilakukan penelitian yang mendalam tentang model strategi pendekatan supply 
chain management pada proses produksi dan saluran distribusi terhadap agroindustri mangga di
Kabupaten Probolinggo, khususnya mangga jenis Arumanis.

\section{KERANGKA KONSEP PENELITIAN}

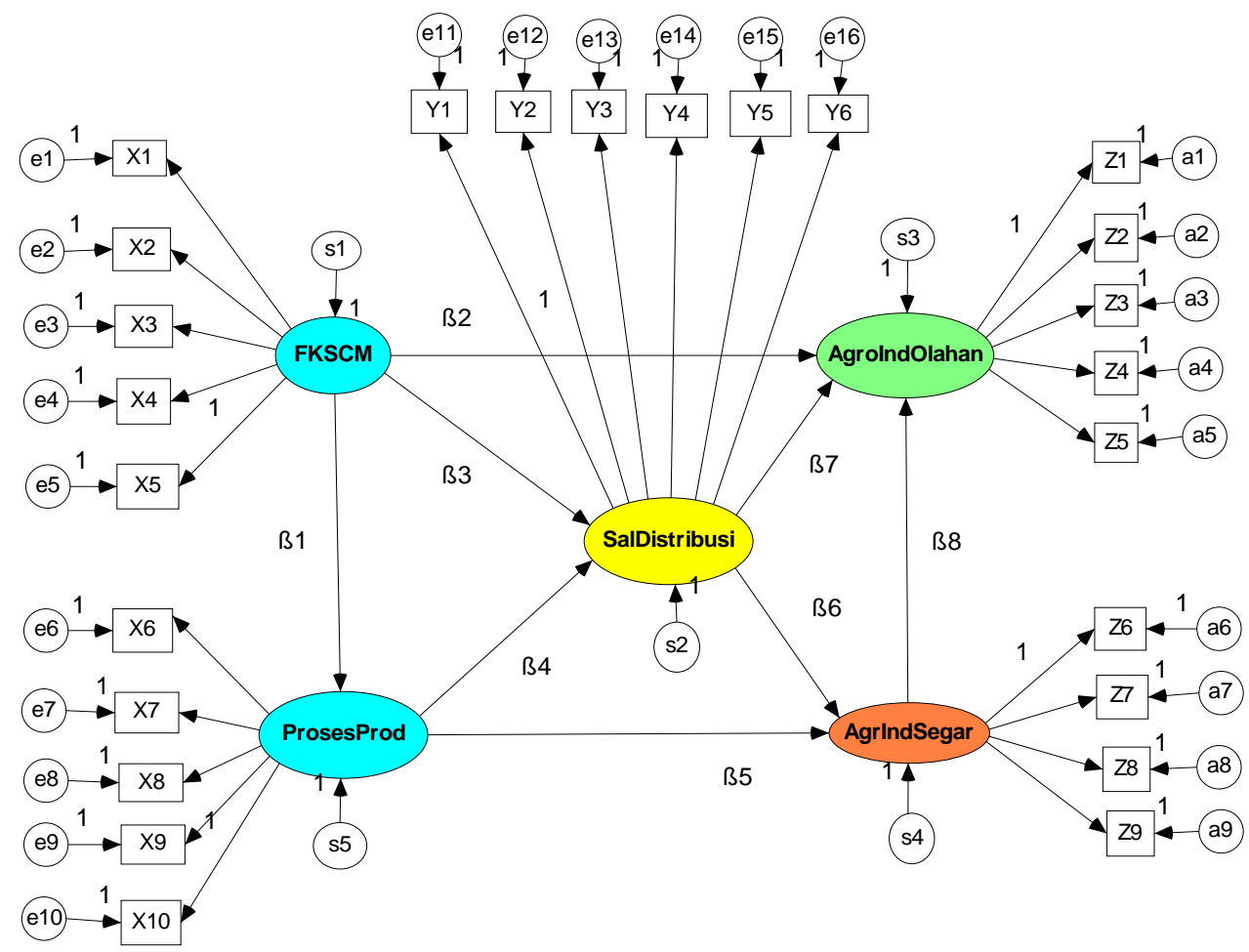

Gambar 1. Model Hipotesis Analisis SEM Strategi Pendekatan SCM pada Proses Produksi dan Saluran Distribusi Terhadap Agroindustri Mangga Arumanis di Kabupaten Probolinggo

METODE PENELITIAN

Tempat dan waktu Penelitian
Penelitian ini dilaksanakan di Kabupaten Probolinggo. Waktu 
penelitian antara bulan Februari 2010 sampai dengan bulan Januari 2011

\section{Metode Pengambilan Sampel}

Menurut Ferdinand (2002), bahwa dengan menggunakan Structural Equation Modeling (SEM) dipakai sampel dengan jumlah minimal 100 dan selanjutnya menggunakan perbandingan 5 observasi untuk setiap estimated parameter, sehingga dalam penelitian ini diperoleh 5 x 25 = 125 sampel.

\section{Metode Pengambilan Data}

Dalam penelitian ini data yang akan digunakan adalah data yang dapat menggambarkan kausalitas yang dapat dihipotesakan antar konstruk yang ada, sehingga memungkinkan untuk menjelaskan sebuah kausalitas, termasuk didalamnya kausalitas berjenjang yang mungkin ada, terutama data primer. Selain data primer dilengkapi dengan data sekunder misalnya karakteristik, produksi, produktivitas dan data lainnya tentang mangga Arumanis di kabupaten Probolinggo.

\section{Analisis SEM}

Analisis ini menggunakan bantuan program AMOS 16 for Windows. Analisis ini untuk menjawab hipotesa-hipotesa penelitian yang diajukan, dengan langkahlangkah sebagai berikut ;

Langkah 1. Pengembangan Model Berbasis Konsep dan Teori

Langkah 2. Mengkonstruksi Path Diagram
Langkah 3. Konversi Path Diagram ke dalam Model Struktural

Langkah 4. Memilih Matrik Input

Langkah 5. Menilai Masalah teridentifikasi

Langkah 6. Evaluasi Goodness of Fit

Langkah 7. Interpretasi dan Modifikasi Model

\section{Analisis Kelembagaan}

Pada bagian ini, elemen struktur kelembagaan dibatasi hanya : 1) Dinas pertanian, 2) Kelompok tani, 3) Dinas Perindustrian dan perdagangan, 4) Koperasi, 5) Perbankan, 6) Perguruan Tinggi. Analisis struktural terhadap kelembagaan pendukung dalam agroindustri mangga Arumanis menggunakan metode ISM. Metode ISM terdiri dari dua tahapan dengan dua kegiatan utama yaitu penyusunan hirarki dan klasifikasi sub elemen.

Klasifikasi sub-elemen mengacu pada hasil olahan dari RM yang telah memenuhi aturan Transitivity. Hasil olahan tersebut didapatkan nilai Driver-Power (DP) dan nilai Dependence (D) untuk menentukan klasifikasi sub elemen yang digolongkan dalam empat sector (Santoso dan Marimin, 2001), yaitu :

- Sektor 1 : Weak driver-weak dependent variables (Aotonomous).

Peubah disektor ini tidak berkaitan dengan system dan mungkin mempunyai hubungan kecil, meskipun 
hubungan tersebut bias kuat

- Sektor 2 : Weak driverstrongly dependent variables (Dependent).

Peubah pada sector ini adalah peubah yang tidak bebas.

- Sektor 3 : Strong driverstrongly dependent variables (Linkage).

Peubah pada sektor ini harus dikaji secara hatihati sebab hubungan antar peubah dalah tidak stabil. setiap tindakan pada peubah tersebut akan memberikan dampak terhadap lainnya dan umpan balik pengaruhnya bisa memperbesar dampak.

- Sektor 4 : Strong driver-weak dependent variables (Independet).

Peubah pada pada sektor ini merupakan bagian sisa dari system dan disebut peubah bebas.

\section{Model Harga}

Programasi Goal Programming (GP) adalah teknik matematis yang digunakan untuk mengalokasikan sumberdaya yang terbatas antara aktivitas yang bersaing untuk memaksimumkan nilai fungsi tujuan (Darmawan, 2004). Model umum untuk permasalahan GP diekspresikan sebagai berikut.

Memaksimumkan (maximize)

$Z=\sum_{j=1}^{n} \quad C_{j} X_{j}$ dengan kendala (subject to):

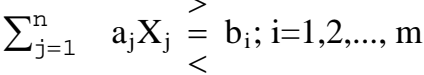

$$
\begin{aligned}
& \text { dan } \quad X_{j} \geq 0
\end{aligned}
$$

dimana: $\mathrm{z}$ adalah fungsi tujuan (objective function) atau fungsi yang harus dimaksimumkan; $\mathrm{x}_{\mathrm{j}}$ adalah aktivitas-aktivitas (activities) atau variabel keputusan (decision variables) $c_{j}$ adalah kontribusi aktivitas ke-j pada nilai fungsi tujuan; $\mathrm{a}_{\mathrm{ij}}$ adalah tingkat penggunaan (atau kontribusinya terhadap) kendala atau persyaratan ke- $b_{i}$ oleh suatu unit aktivitas ke-j; $b_{i}$ adalah tingkat sumberdaya atau persyaratan. Persamaan kendala dan kondisi nonnegatif yang harus dipenuhi dalam optimisasi. Lebih spesifik, diilustrasikan sebagai berikut.

Memaksimumkan: $\mathrm{z}=\mathrm{c}_{1} \mathrm{x}_{1}+\ldots$ $+\mathrm{c}_{\mathrm{j}} \mathrm{x}_{\mathrm{j}}+\ldots+\mathrm{c}_{\mathrm{n}} \mathrm{x}_{\mathrm{n}}$ dengan kendala: $\mathrm{a}_{11} \mathrm{x}_{1}+\ldots+$ $\mathrm{a}_{1 \mathrm{j}} \mathrm{x}_{\mathrm{j}}+\ldots+\mathrm{a}_{1 \mathrm{n}} \mathrm{x}_{\mathrm{n}} \stackrel{>}{=} \underset{<}{<}$

$\mathrm{a}_{\mathrm{ijj}} \mathrm{x}_{\mathrm{j}}+\ldots+\mathrm{a}_{\mathrm{in}} \mathrm{x}_{\mathrm{n}} \stackrel{>}{=} \mathrm{b}_{\mathrm{i}}$ $\mathrm{a}_{\mathrm{i} 1} \mathrm{x}_{1}+\ldots+$ 


$$
\mathrm{a}_{\mathrm{m} 1} \mathrm{x}_{1}+\ldots
$$$$
\begin{aligned}
+a_{m j} x_{j}+\ldots+a_{m n} x_{n} & >b_{m} \\
& <
\end{aligned}
$$

$$
\begin{aligned}
& \text { dan } \\
& \mathrm{x}_{\mathrm{j}} \geq 0
\end{aligned}
$$

dimana: $\mathrm{z}$ adalah fungsi tujuan; $\mathrm{x}_{\mathrm{j}}$ adalah alternatif aktivitas dalam produksi, konsumsi, pemasaran dan keuangan; $\quad b_{i}$ adalah kendala: persyaratan $(>)$, pembatas (restriction) $(<)$, persamaan $(=) ; \quad a_{i j}$ adalah penambahan untuk $(<0)$ atau pengurangan dari $(>0) b_{i}$ oleh suatu unit $\mathrm{x}_{\mathrm{j}} ; \mathrm{c}_{\mathrm{j}}$ adalah penambahan untuk $(>0)$ atau pengurangan dari $(<0) \mathrm{z}$ oleh suatu unit $\mathrm{x}_{\mathrm{j}}$; Baris $\mathrm{m}$ yang pertama di bawah fungsi tujuan (z) dan kolom $n$ yang pertama menunjukkan matriks LP konvensional.

\section{Model Transportasi}

$$
\text { Masalah }
$$

transportasi

(transportation problem) berhubungan dengan distribusi produk tunggal dari beberapa sumber, dengan penawaran (supply) terbatas, menuju beberapa tujuan, dengan permintaan (demand) tertentu, pada biaya transpor minimum. Karena hanya ada satu macam barang, maka permintaan suatu tempat tujuan dapat dipenuhi dari satu atau lebih sumber (Darmawan, 2004). Asumsi dasar model transportasi adalah biaya transpor pada suatu rute tertentu proporsional terhadap jumlah unit yang dikirim. Model matematis masalah transportasi adalah sebagai berikut:

$$
\text { Meminimalkan } \mathrm{C}_{\mathrm{t}}=\sum_{\mathrm{i}=1}^{\mathrm{m}}
$$

$$
\sum_{j=1}^{\mathrm{n}} \mathrm{C}_{\mathrm{ij}} \mathrm{X}_{\mathrm{ij}}
$$

dengan kendala $\sum_{\mathrm{j}=1}^{\mathrm{n}} \mathrm{X}_{\mathrm{ij}}=$ $\mathrm{S}_{\mathrm{i}}$ (supply, $\left.\mathrm{i}=1,2, \ldots, \mathrm{m}\right)$

$$
\sum_{\mathrm{i}=1}^{\mathrm{m}} \mathrm{X}_{\mathrm{ij}}=\mathrm{D}_{\mathrm{j}} \quad \text { (demand, }
$$

$j=1,2, \ldots, n)$

Kondisi keseimbangan

dicapai jika supply = demand .

Metode untuk mencari solusi layak dasar awal (initial solution), Vogel's Approximation Method (VAM). Metode ini digunakan, karena selalu memberikan solusi awal yang lebih baik dibandingkan dengan metode lainnya. Setelah solusi awal diperoleh, kemudian dilakukan perbaikan untuk mencari solusi optimal dengan Stepping-Stone.

\section{HASIL PENELITIAN DAN PEMBAHASAN}

\section{Hasil Analisis Data}

Hasil Analisis Structural Equation Modelling (SEM)

Hasil analisis uji Goodnessof-Fit Overall Model SEM tahap awal disajikan pada Tabel 1, sedangkan hasil analisis hasil uji Goodnes-of-Fit Overall Model SEM tahap akhir tersebut disajikan pada Tabel 2. 


\begin{tabular}{|l|c|c|c|}
\hline \multicolumn{1}{|c|}{ Kriteria } & Nilai Kritis & Hasil Uji Model & Keterangan \\
\hline$\chi^{2}-$ Chi Square & Kecil \& & $560,649(\mathrm{p}=0,000)$ & Belum Memenuhi Syarat \\
Chi Square/DF & nonsignifikan & 2,1 & Belum Memenuhi Syarat \\
RMSEA & $\leq 2,00$ & 0,097 & Belum Memenuhi Syarat \\
GFI & $\leq 0,08$ & 0,720 & Belum Memenuhi Syarat \\
AGFI & $\geq 0,90$ & 0,659 & Belum Memenuhi Syarat \\
TLI & $\geq 0,90$ & 0,812 & Belum Memenuhi Syarat \\
& $\geq 0,90$ & & \\
\hline
\end{tabular}

Tabel 2. Nilai Goodness-of-Fit dan Nilai Kritis SEM Tahap Akhir

\begin{tabular}{|l|c|c|l|}
\hline \multicolumn{1}{|c|}{ Kriteria } & Nilai Kritis & Hasil Uji Model & \multicolumn{1}{c|}{ Keterangan } \\
\hline$\chi^{2}-$ Chi Square & Kecil \& nonsignifikan & $318,348(\mathrm{p}=0,000)$ & Model Marginal \\
Chi Square/DF & $\leq 2,00$ & 1,553 & Model Baik \\
RMSEA & $\leq 0,08$ & 0,069 & Model Baik \\
GFI & $\geq 0,90$ & 0,838 & Model Marginal \\
AGFI & $\geq 0,90$ & 0,774 & Model Marginal \\
TLI & $\geq 0,90$ & 0,905 & Model Baik \\
\hline
\end{tabular}

Pembahasan Hasil

Pengaruh Faktor Keberhasilan Supply Chain Management Terhadap Proses Produksi

Koefisisen pengaruh Faktor Keberhasilan Supply Chain Management (FKSCM) Terhadap Proses Produksi (ProsesProd) adalah sebesar 0,809 , serta memiliki tingkat signifikansi dengan $p$-value sebesar 0,000 (jauh dibawah 0,05). Hal tersebut berarti proses produksi sangat dipengaruhi oleh faktor keberhasilan supply chain management. Koefisien struktural faktor keberhasilan supply chain management pada proses produksi adalah sebesar 0,809 , ini dapat diartikan bahwa setiap 0,809 unit kenaikan keberhasilan supply chain management akan meningkatkan tingkat proses produksi sebesar 1 unit.
Konsep SCM meliputi 6 prinsip seperti yang dikembangkan oleh AFFA (Australian,Department of Forestry and Fisheries) antara lain fokus pada konsumen dan pelanggan, rantai selalu menciptakan dan berbagi nilai antar aktor, membuat produk betul-betul memenuhi spesifikasi pelanggan, logistik dan distribusi yang efektif, sebuah strategi informasi dan komunikasi yang melibatkan setiap aktor, hubungan yang efektif yang makin merekatkan dan berbagi kepemilikan (Woods, 2003).

\section{Pengaruh Faktor Keberhasilan Supply Chain Management Terhadap Saluran distribusi \\ koefisisen pengaruh Faktor Keberhasilan Supply Chain Management (FKSCM) Terhadap Saluran distribusi (SalDistribusi)}


adalah sebesar 0,673 , serta memiliki tingkat signifikansi dengan $p$-value sebesar 0,000 (jauh dibawah 0,05). Hal tersebut berarti saluran distribusi sangat dipengaruhi oleh faktor keberhasilan supply chain management. Koefisien struktural faktor keberhasilan supply chain management pada saluran distribusi adalah sebesar 0,673, ini dapat diartikan bahwa setiap 0,673 unit kenaikan keberhasilan supply chain management akan meningkatkan tingkat saluran distribusi sebesar 1 unit.

Pendekatan SCM didasarkan pada; (a) Proses budidaya untuk menghasilkan produk (hortikultura), (b) Mentransformasikan bahan mentah (penanganan panen dan pasca panen), dan (c) Pengiriman produk ke konsumen melalui sistem distribusi. Untuk menjamin keberhasilan penerapan Supply Chain Management (SCM) atau Manajemen Pengelolaan Rantai Pasokan perlu memahami faktor-faktor pendukung keberhasilan antara lain : kebijakan, sumber daya manusia, prasarana, sarana, teknologi, kelembagaan, modal/ pembiayaan, sistem informasi, sosial budaya dan lingkungan lain (Saptana $d k k ., 2006$ ).

Chomchalow et al. (2008) telah melakukan kajian tentang kekuatan industri buah-buahan di Thailand. Kekuatan tersebut adalah mayoritas (90\%) merupakan pemilik lahan dan petani yang professional, sehingga mereka mampu menangani bisnis secara efektif. Adanya pusat transportasi untuk tujuan pasar dunia, termasuk didalamnya sarana penyimpanan yang baik untuk pengiriman pasar domestik dan mengekspor melalui udara dan laut. Kondisi iklim di Thailand sangata sesuai untuk menghasilkan buahbuahan tropis yang berkualitas seperti mangga, durian, manggis, nanas dan rambutan

\section{Pengaruh Faktor Keberhasilan Supply Chain Management Terhadap Agroindustri Olahan}

Koefisisen pengaruh Faktor Keberhasilan Supply Chain Management (FKSCM) Terhadap Agroindustri olahan (AgrIndOlahan) adalah sebesar 0,095 , serta memiliki tingkat signifikansi dengan $p$-value sebesar 0,524 (di atas 0,05). Hal tersebut berarti agroindustri olahan tidak dipengaruhi oleh faktor keberhasilan supply chain management. Koefisien struktural faktor keberhasilan supply chain management pada agroindustri olahan adalah sebesar 0,095, ini dapat diartikan bahwa setiap 0,095 unit kenaikan keberhasilan supply chain management akan meningkatkan tingkat agroindustri olahan sebesar 1 unit. Meskipun koefisien strukturalnya kecil, apabila ditingkatkan, maka akan meningkat pula agroindustri olahan mangga Arumanis.

Sistem informasi dalam supply chain sangat diperlukan, karena perusahaan dapat membangun kerjasama melalui penciptaan jaringan kerja (network) yang terkoordinasi dalam penyediaan barang maupun jasa 
bagi konsumen secara efisien (D'Amours et al., 1999). Salah satu hal terpenting dalam manajemen rantai pasokan adalah saling berbagi informasi, oleh karena itu dalam aliran material, aliran kas, dan aliran informasi merupakan keseluruhan elemen dalam rantai pasokan yang pertu diintegrasikan (Chen et al., 2004).

\section{Pengaruh Proses Produksi Terhadap Saluran Distribusi}

Koefisisen pengaruh proses produksi (ProsesProd) Terhadap Saluran distribusi (SalDistribusi) adalah sebesar 0,583 , serta memiliki tingkat signifikansi dengan $p$-value sebesar 0,000 (jauh dibawah 0,05). Hal tersebut berarti saluran distribusi sangat dipengaruhi oleh faktor proses produksi. Koefisien struktural faktor proses produksi pada saluran distribusi adalah sebesar 0,583, ini dapat diartikan bahwa setiap 0,583 unit kenaikan proses produksi akan meningkatkan tingkat saluran distribusi sebesar 1 unit.

Buurma dan Saranark (2006) menyatakan bahwa perencanaan pengembangan supply chain di Thailand bertujuan memenuhi pasar ekspor buah segar dengan memfokuskan pada dua kegiatan yaitu, pendirian pusat pengemasan dan distribusi di Bandara yang bertujuan untuk mengendalikan kualitas dan keamanan pangan. Selain itu juga didirikannya pusat penanganan pasca panen di setiap propinsi yang bertujuan untuk menangani pembelian dari para petani sampai ke pedagang besar.

Pengangkutan atau transportasi buah sebenarnya sudah dimulai dari kebun menuju pengumpul atau bangsal pengemasan (packing house) di sentra produksi. Kondisi pengangkutan sangat tergantung dari fasilitas lokal yang tersedia atau yang dimiliki petani/pekebun. Yang dimaksud dengan bangsal pengemasan juga bervariasi mulai dari halaman rumah, bangunan milik pedagang pengumpul sampai bangsal pengemasan lengkap dengan segala perlengkapannya . Beragam cara pengangkutan buah dari kebun, antara lain: diangkut dengan dipikul langsung oleh petani, gerobak dorong, diangkut dengan sepeda/sepeda motor, mobil bak terbuka dan lainnya. Untuk daerah di luar Jawa banyak menggunakan berbagai jenis angkutan sungai. Setelah pengemasan di tempat pengumpul atau bangsal pengemasan, berbagai jenis alat transportasi yang lebih besar dapat digunakan untuk pengiriman (Hui et al., 2003).

\section{Pengaruh Proses Produksi Terhadap Agroindustri Segar} Koefisisen pengaruh proses produksi (ProsesProd) Terhadap Agroindustri segar (AgrIndSegar) adalah sebesar 0,121 , serta memiliki tingkat signifikansi dengan $p$-value sebesar 0,038 (dibawah 0,05). Hal tersebut berarti agroindustri segar sangat dipengaruhi oleh proses produksi. Koefisien struktural faktor proses produksi pada agroindustri 
segar adalah sebesar 0,121 , ini dapat diartikan bahwa setiap 0,121 unit kenaikan proses produksi akan meningkatkan tingkat agroindustri segar sebesar 1 unit.

Saluran pemasaran buah mangga segar secara umum harus didukung oleh lima komponen yang saling berinteraksi, yaitu (1) Pusat Informasi mangga dan kebun bibit, (2) kemitraan sistem produksi antara kebun mangga rakyat dan kebun mangga monokultur, (3) kelembagaan transfer informasi teknologi inovatif, (4) penanganan pascapanen, dan (5) Sistem pemasaran dan informasi pasar buah mangga, termasuk pasar ekspor Soemarno dkk. (2009).

\section{Pengaruh Saluran Distribusi Terhadap Olahan}

Koefisisen pengaruh Saluran distribusi (SalDistribusi) terhadap Agroindustri olahan (AgrIndOlahan) adalah sebesar 0,145 , serta memiliki tingkat signifikansi dengan $p$-value sebesar 0,187 (di atas 0,05). Hal tersebut berarti agroindustri olahan tidak dipengaruhi oleh saluran distribusi. Koefisien struktural saluran distribusi pada agroindustri olahan adalah sebesar 0,145, ini dapat diartikan bahwa setiap 0,145 unit kenaikan saluran distribusi akan meningkatkan tingkat agroindustri olahan sebesar 1 unit. Meskipun koefisien strukturalnya kecil, apabila ditingkatkan, maka akan meningkat pula agroindustri olahan mangga Arumanis

Setyabudi et al. (2007), potensi agroindustri berdampak terhadap penentuan kebijakan, baik pemasaran, ekonomi, distribusi, dan investasi, berguna bagi industry bidang pengolahan, dan industri lainnya serta berdampak pada lapangan kerja, baik di tingkat pedesaan, nasional, dan menyangkut daerah lainnya.

\section{Pengaruh Saluran Distribusi} Terhadap Agroindustri Segar

Koefisisen pengaruh Saluran distribusi (SalDistribusi) terhadap Agroindustri segar (AgrIndSegar) adalah sebesar 0,413, serta memiliki tingkat signifikansi dengan $p$-value sebesar 0,000 (di bawah 0,05). Hal tersebut berarti agroindustri segar dipengaruhi oleh saluran distribusi. Koefisien struktural saluran distribusi pada agroindustri segar adalah sebesar 0,413 , ini dapat diartikan bahwa setiap 0,413 unit.

Pemilihan moda transportasi untuk pengiriman buah didasari oleh beberapa faktor, antara lain: tempat tujuan, nilai ekonomi buah, tingkat kepekaan/kemudahan produk menjadi rusak, kuantitas, kondisi transportasi yang dipersyaratkan, kondisi iklim tempat asal dan tempat tujuan, waktu tempuh yang diinginkan sampai tujuan, tarif/biaya

\section{Pengaruh Agroindustri Segar Terhadap Agroindustri Olahan}




\section{Koefisisen}

pengaruh

Agroindustri segar (AgrIndSegar) terhadap Agroindustri olahan (AgrIndOlahan) adalah sebesar 0,498, serta memiliki tingkat signifikansi dengan p-value sebesar 0,003 (di bawah 0,05). Hal tersebut berarti agroindustri olahan dipengaruhi oleh agroindustri segar. Koefisien struktural agroindustri segar pada agroindustri olahan adalah sebesar 0,498, ini dapat diartikan bahwa setiap 0,498 unit kenaikan agroindustri segar akan meningkatkan tingkat agroindustri olahan sebesar 1 unit.

\section{Faktor Dominan yang Berpengaruh Terhadap Mangga Arumanis}

Hasil penelitian di atas menunjukkan faktor-faktor yang berpengaruh secara dominan terhadap pengembangan agroindustri mangga Arumanis segar dan olahan di Kabupaten Probolinggo adalah ; 1) indikator kelembagaan dari variabel faktor keberhasilan SCM, 2) indikator harga dari variabel proses produksi dan 3) indikator transportasi dari variabel saluran distribusi.

\section{Analisis Kelembagaan}

Analisis struktur untuk mengembangkan agroindustri mangga Arumanis segar dan olahan di Kabupaten Probolinggo sebagai produk yang optimal perlu didukung oleh kelembagaan yang memadai. Dalam penelitian ini, elemen struktur kelembagaan dibatasi pada beberapa pelaku yang dianggap cukup berperan dalam kelembagaan agroindustri mangga Arumanis segar dan olahan, yaitu : 1) Lembaga Perguruan Tinggi, 2) Dinas Pertanian, 3) Perbankan, 4) Pengusaha Agoindustri Mangga Arumanis Skala Kecil dan Menengah, 5) Kluster, 6) Kadin, 7) Pedagang Perantara (Agen), 8) Disperindag, dan 9) Koperasi.

Hasil analisis kelembagaan secara struktural dengan teknik ISM disajikan pada Gambar 2, bahwa elemen kunci kelembagaan adalah Disperindag (8). Hal ini menunjukkan bahwa, keberhasilan pengembangan agroindustri mangga Arumanis segar dan olahan di Kabupaten Probolinggo sangat ditentukan oleh kemampuan dan kinerja Dinas perindustrian dan perdagangan (Disperindag) dalam menetapkan kebijakan yang dimiliki.

Sedangkan pihak Lembaga Perguruan Tinggi (1), Dinas Pertanian (2), Perbankan (3), Pengusaha Agroindustri Mangga Arumanis Skala Kecil dan Menengah (4), Pedagang Perantara (Agen) (7), dan Koperasi (9) termasuk dalam sektor III. Elemenelemen pada sektor III ini merupakan peubah yang harus dikaji secara hatihati, sebab hubungan antar peubah tidak stabil dan dapat memberikan dampak berhasil tidaknya suatu pengembangan agroindustri mangga Arumanis segar dan olahan di Kabupaten Probolinggo. Hal ini berarti aparat birokrasi di daerah harus mampu menciptakan iklim yang kondusif yang mendorong berkembangnya agroindustri, antara lain melalui kebijakan yang memihak 
kepada Pengusaha Agroindustri Mangga Arumanis Skala Kecil dan Menengah. Lembaga Kluster dan Kadin terletak pada sektor II adalah peubah tidak bebas.

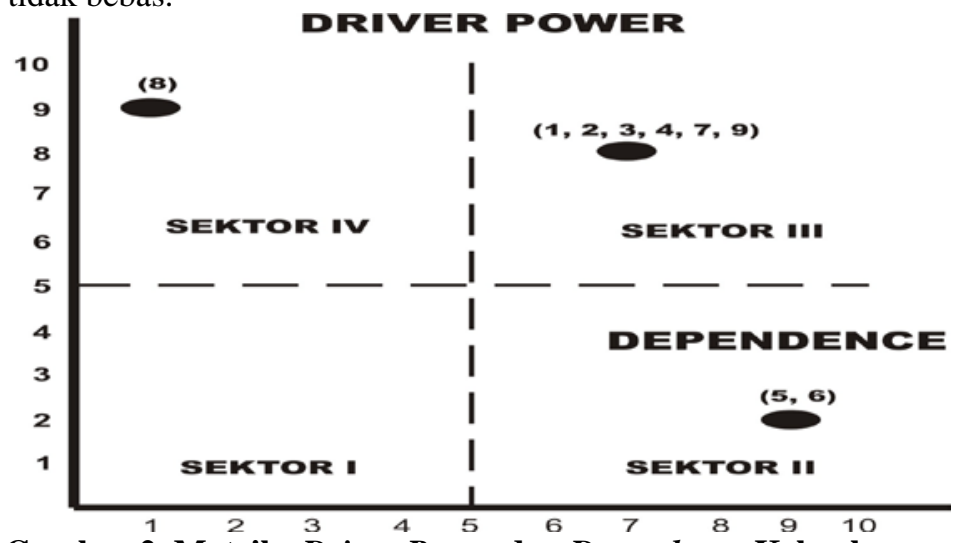

Gambar 2. Matriks Driver-Power dan Dependence Kelembagaan

Gumbira dan Haritz (2001) menyatakan keberadaan kelembagaan pendukung pengembangan agribisnis nasional sangat penting untuk menciptakan agroindustri Indonesia yang tangguh dan kompetitif. Lembaga-lembaga pendukung tersebut sangat menentukan dalam upaya menjamin terciptanya integrasi agribisnis dalam mewujudkan tujuan pengembangan agribisnis. Beberapa lembaga pendukung pengembangan agribisnis Indonesia adalah pemerintah, (2) lembaga pembiayaan, (3) lembaga pemasaran dan distribusi, (4) koperasi, (5) lembaga pendidikan formal dan informal, (6) lembaga penyuluhan pertanian lapangan, dan (7) lembaga penjamin dan penanggungan risiko.
Thailand

mempunyai keunggulan pengembangan agribisnis hortikultura yang lebih baik dari negara lain, hal ini disebabkan adanya 1) Kerjasama yang terpadu antara pengusaha, masyarakat dan pemerintah sangat langgeng dan berkesimbangungan, di mana ide-ide dan motivasi pengusaha berkembang dengan mendapat dukungan dari pemerintah untuk merealisasikannya, dan 2) Koordinasi antara instansi pemerintah dengan asoiasi-asosiasi sangat baik, terutama dengan board of trade (BOT), Federation of Thaiindustry Assoiation (FTA), dan Thailand Banking Assosiation (TBA) (Antara, 2004).

\section{Analisis Harga}


Ringkasan Goal (G) harga jual optimal mangga Arumanis A, B, C yang diperoleh petani, pemasok serta eksportir di masing-masing kecamatan disajikan pada Tabel 3.

Tabel 3. Harga Jual Optimal Mangga Arumanis Grade A, B, dan C

\begin{tabular}{|c|l|c|}
\hline Grade & Variabel & $\begin{array}{c}\text { Maksimal } \\
\text { Harga Jual (Rp/Kg) }\end{array}$ \\
\hline \multirow{3}{*}{ A } & Petani & 15.376 \\
\cline { 2 - 3 } & Pemasok & 28.269 \\
\cline { 2 - 3 } & Eksportir & 39.201 \\
\hline \multirow{3}{*}{ B } & Petani & 5.916 \\
\cline { 2 - 3 } & Pemasok & 11.716 \\
\cline { 2 - 3 } & Eksportir & 32.083 \\
\hline \multirow{2}{*}{ C } & Petani & 2.386 \\
\cline { 2 - 3 } & Pemasok & 5.447 \\
\hline
\end{tabular}

Tabel 3 menyajikan maksimal harga jual optimal mangga Arumanis Grade A berkisar antara Rp. 15.376 sampai Rp. 39,201, Grade B Rp. 5.916, sampai Rp. 11.716, dan Grade C Rp. 2.386 sampai 5.447,--

Harga jual buah-buahan dalam konteks supply chain management sangatlah penting, menyadari bahwa kualitas ditentukan oleh semua pihak dalam supply chain, termasuk supplier tentunya (Cousin dan Speakman, 2003). Sedangkan pengendalian mutu untuk buah segar kualitas ekspor harus sesuai dengan Standard Operasional Prosedure (SOPs) yang ditetapkan oleh Departemen pertanian, karena sangat berpengaruh terhadap harga jual

Tabel 4. Ringkasan Model Matematis dan Minimum Total Biaya Transportasi Mangga Arumanis Grade A, B, C masing-masing Grade (Buurma dan Saranark, 2006).

\section{Analisis Transportasi}

Analisis transportasi sangat diperlukan dalam mengembangkan agroindustri di Kabupaten Probolinggo, karena transportasi digunakan untuk mengatur distribusi dari sumber-sumber yang menyediakan produk yang sama, ke tempat-tempat yang membutuhkan secara optimal. Ringkasan model matematis dan minimum total biaya transportasi mangga Arumanis di Kabupaten Probolinggo Grade A, B, C disajikan pada Tabel 4. 


\begin{tabular}{|c|c|c|}
\hline Grade A & $\begin{aligned} \mathrm{z}= & 25 \mathrm{X}_{\mathrm{PA}}+60 \mathrm{X}_{\mathrm{PB}}+60 \mathrm{X}_{\mathrm{PC}}+40 \mathrm{X}_{\mathrm{PD}}+47 \mathrm{X}_{\mathrm{PE}} \\
& +4 \mathrm{X}_{\mathrm{PH}}+4 \mathrm{X}_{\mathrm{PI}}+43 \mathrm{X}_{\mathrm{QE}}+57 \mathrm{X}_{\mathrm{QG}}+60 \mathrm{X}_{\mathrm{RF}} \\
& +3 \mathrm{X}_{\mathrm{RG}}\end{aligned}$ & Rp. 361.285 .00 \\
\hline Grade B & $\begin{aligned} \mathrm{z}= & 10 \mathrm{X}_{\mathrm{PA}}+30 \mathrm{X}_{\mathrm{PB}}+30 \mathrm{X}_{\mathrm{PC}}+20 \mathrm{X}_{\mathrm{PD}}+30 \mathrm{X}_{\mathrm{PE}} \\
& +15 \mathrm{X}_{\mathrm{QE}}+40 \mathrm{X}_{\mathrm{QF}}+15 \mathrm{X}_{\mathrm{QG}}+40 \mathrm{X}_{\mathrm{RG}} \\
& +0,5 \mathrm{X}_{\mathrm{RH}}+0,5 \mathrm{X}_{\mathrm{RI}}\end{aligned}$ & Rp. 153.495 .00 \\
\hline Grade C & $\begin{aligned} \mathrm{z}= & 5 \mathrm{X}_{\mathrm{PA}}+30 \mathrm{X}_{\mathrm{PB}}+30 \mathrm{X}_{\mathrm{PC}}+20 \mathrm{X}_{\mathrm{PD}}+15 \mathrm{X}_{\mathrm{PE}} \\
& +35 \mathrm{X}_{\mathrm{QE}}+20 \mathrm{X}_{\mathrm{QF}}+20 \mathrm{X}_{\mathrm{RG}}\end{aligned}$ & Rp. 89.075,000 \\
\hline
\end{tabular}

\section{Implikasi Kebijakan}

Implikasi kebijakan model strategi pendekatan keberhasilan supply chain management pada proses produksi dan saluran distribusi terhadap agroindustri mangga Arumanis di kabupaten Probolinggo, yaitu :

A. Implikasi kebijakan model strategi pendekatan supply chain management pada proses produksi terhadap agroindustri mangga Arumanis di Kabupaten Probolinggo, meliputi ;

1. Pembinaan sumberdaya manusia, khususnya petani mangga Arumanis melalui penyuluhan dan pelatihan tentang SOP mangga Arumanis, yang bertujuan untuk meningkatkan kuantitas dan kualitas mangga Arumanis sesuai dengan kebutuhan pasar lokal maupun ekspor.

2. Perbaikan sarana dan prasarana mangga Arumanis, meliputi ; 1) sarana jalan usaha tani, 2) sarana jalan produksi, 3) klinik konsultasi kesehatan tanaman, dan 4) laboratoriun pelayanan uji standar dan mutu mangga Arumanis. Perbaikan sarana dan prasarana bertujuan untuk meningkatkan kualitas (berat, tingkat ketuaan, kekerasan, keseragaman ukuran dan jumlah mangga busuk maksimum) mangga Arumanis sesuai dengan kebutuhan pasar lokal maupun ekspor

3. Perbaikan dan peningkatan teknologi pada mangga Arumanis, meliputi ; 1) teknologi pembibitan, 2) teknologi budidaya, 3) teknologi panen dan 4) teknologi pasca panen. Perbaikan dan peningkatan teknologi bertujuan untuk meningkatkan kuantitas dan kualitas (berat, tingkat ketuaan, kekerasan, keseragaman ukuran dan jumlah mangga busuk maksimum) mangga Arumanis sesuai dengan kebutuhan pasar lokal maupun ekspor, baik yang di 
jual dalam bentuk segar maupun olahan.

4. Memaksimalkan

pemanfaatan sistem informasi pemasaran mangga Arumanis, meliputi ; 1) harga, 2) tujuan pasar, 3) daya serap pasar, dan 4) jumlah permintaan pasar. Sistem informasi ini bertujuan untuk mendapatkan informasi pasar mangga Arumanis secara cepat dengan perolehan data yang bersifat up to date, sehingga penentuan harga jual mangga Arumanis dapat dioptimalkan.

5. Peningkatan peran serta kelembagaan, meliputi ; 1) pemerintah (Disperindag), 2) lembaga pembiayaan (perbankan), 3) lembaga pemasaran dan distribusi (Pengusaha Agoindustri Mangga Arumanis Skala Kecil dan Menengah, Kadin, dan Pedagang perantara), 4) koperasi, 5) lembaga pendidikan formal dan informal, 6) lembaga penyuluhan pertanian lapangan (Dinas Pertanian), dan 7) lembaga riset (Perguruan Tinggi). Peningkatan keikutsertan kelembagaan bertujuan, 1) memperbaiki kuantitas dan kualitas mangga Arumanis baik untuk segar maupun olahan, 2) memberikan sistem informasi harga jual optimal mangga Arumanis secara cepat dengan perolehan data yang bersifat up to date, dan 3) perbaikan dan peningkatan teknologi pembibitan, budidaya, panen dan pasca panen.

B. Implikasi kebijakan model strategi supply chain management pada saluran distribusi terhadap agroindustri mangga Arumanis di Kabupaten Probolinggo, meliputi ;

1. Memaksimalkan pemanfaatan sistem informasi pemasaran mangga Arumanis, bertujuan untuk mempercepat proses layanan saluran distribusi pada pengambilan resiko yang meliputi, 1) pemrosesan pesanan, 2) banyaknya persediaan, dan 3) pengiriman barang pesanan

2. Perbaikan sarana dan prasarana penyimpanan mangga Arumanis, meliputi ; 1) meliputi gudang sementara dari produsen, 2) cold storage, 3) gudang mangga Arumanis.

3. Peningkatan dan perbaikan sarana transportasi untuk pengembangan agrondustri mangga Arumanis, dapat dilakukan dengan cara ; meminimalkan total biaya transportasi dan waktu transit (transit time), meningkatkan 
keterandalan (reliability) dan kemampuan (capability) moda transportasi mangga Arumanis

4. Perbaikan dan peningkatan jaminan pelayanan sesudah pembelian mangga Arumanis dengan cara ; 1) penanganan yang cepat dan tepat, 2) kemudahan penggantian mangga Arumanis, apabila tidak sesuai dengan standar yang telah ditentukan oleh pembeli, dan 3) kecepatan penanganan dalam layanan pemrosesan, apabila tidak sesuai dengan standar yang telah ditentukan oleh pembeli

5. Adanya dukungan lembaga pembayaran dan pendanaan yang bersifat sederhana, mudah, cepat, dan murah pada pengembangan agroindustri mangga Arumanis.

\section{Temuan Penelitian}

Temuan dari penelitian ini menghasilkan empat model, yaitu ;

1. Model strategi pendekatan supply chain management pada proses produksi dan saluran distribusi terhadap agroindustri mangga Arumanis di Kabupaten Probolinggo

2. Model kelembagaan agroindustri mangga Arumanis di tiga Kecamatan (Besuk, Krejengan dan Pajarakan) Kabupaten Probolinggo.
3. Model harga jual optimal mangga Arumanis Grade A, B, C di tiga Kecamatan (Besuk, Krejengan dan Pajarakan) Kabupaten Probolinggo.

4. Model transportasi dengan mencari total biaya minimum transportasi mangga Arumanis Grade A, B, C di tiga Kecamatan (Besuk, Krejengan dan Pajarakan) Kabupaten Probolinggo.

\section{KESIMPULAN DAN SARAN}

\section{Kesimpulan}

Berdasarkan hasil penelitian, analisis data dan pembahasan pada bab-bab sebelumnya, maka diperoleh kesimpulan sebagai berikut.

1. Faktor keberhasilan supply chain management (pembinaan SDM, sarana prasarana, teknologi, kelembagaan dan sistem informasi) pada proses produksi dan saluran distribusi berpengaruh positif dan signifikan terhadap agroindustri mangga Arumanis di Kabupaten Probolinggo.

2. Faktor dominan yang paling berpengaruh terhadap agroindustri mangga Arumanis di Kabupaten Probolinggo adalah variabel faktor keberhasilan supply chain management dengan indikator paling dominan kelembagaan, proses produksi dengan indikator paling dominan harga dan saluran distribusi dengan indikator paling dominan trasportasi. 
3. Implikasi kebijakan model strategi supply chain management pada

4. produksi dan saluran distribusi terhadap agroindustri mangga Arumanis di Kabupaten Probolinggo, ada dua ;

a) Implikasi kebijakan model strategi supply chain management pada proses produksi terhadap agroindustri mangga Arumanis di Kabupaten Probolinggo, lebih difokuskan pada perbaikan dan peningkatan kuantitas, kualitas, penanganan panen, penanganan pasca panen, dan harga jual mangga Arumanis

\section{Saran}

1. Peneliti lanjut disarankan untuk melakukan penelitian dengan menerapkan model strategi pendekatan keberhasilan supply chain management pada proses produksi dan saluran distribusi terhadap agroindustri mangga Arumanis di Kabupaten Probolinggo dari hasil penelilian ini, dan membandingkan dengan model-model strategi pendekatan keberhasilan supply chain management yang lain untuk dilihat kinerianya.

2. Peneliti lanjut disarankan untuk mempertimbangkan perlunya proses

b) Implikasi kebijakan model strategi supply chain management pada saluran distribusi terhadap agroindustri mangga Arumanis di Kabupaten Probolinggo, lebih difokuskan pada perbaikan dan peningkatan layanan pengambilan resiko, penyimpanan, pemilihan pengangkutan/ transportasi, pelayanan sesudah pembelian, pendanaan dan pembayaran mangga Arumanis

melibatkan variabel lain, memodifikasi indikator pada variabel suply chain management dengan rnenambahkan indikator modal dan jenis moda transportasi untuk meminimalkan biaya transportasi dan meningkatan profit/keuntungan. Peneliti laniut disarankan untuk melakukan penelitian lebih mendalam pada agroindustri mangga Arumamis olahan dan segar dengan responden yang lebih luas dan pada responden agroindustri untuk produk yang lain. 



\section{DAFTAR PUSTAKA}

Antara, M. 2004. Antara Pengembangan Usaha Hortikultura Petani Kecil. Fakultas Pertanian Universitas Udayana, Denpasar-Bali.

Batt, P. J. 2004. Incorporating Measures of Satisfaction, Trust and Powerdependence into an Analysis of Agribusiness Supply Chains. Proceedings. Austarlian Centre fo International Agricultural research. Canberra

Chen, I. J., Paulraj, A. dan Lado, A. A. 2004. Strategic Purchasing, Supply Management and Firm Performance. Journal Operations Management 22, pp. 505 - 523.

Chomchalow, N and P. N. Songkhla. 2008. Thai Mango Export: A Slow-butSustainable Development. Australian Journal Technology 12(1), pp. 18

Darmawan, D.P. 2004. QM/QS Analisis Kuantitatif untuk Manajemen. Jurusan Sosial Ekonomi Pertanian. Fakultas Pertanian. Universitas Udayana.

D'Amours, S., Montreuil, B., Lefrancois., 1999 . Networked Manufacturing: The Impact of Information Sharing. International Journal of Production Economics 58, pp. 63-79

Deptan, 2009. Kualitas Mangga Probolinggo Jeblok.

http://www.probolinggokab.go.id/site/index.php. diakses tanggal 7 Juli 2010

Disperta, 2009. Pertanian Tanaman Pangan. Dinas Pertanian Kabupaten Probolinggo.

FAO, 2007. Agroindustrial Supply Chain Management : Concepts and Applications. Food and Agriculture Organization of The United Nations.

Ferdinand, A. 2002. Structural Equation Modelling dalam Penelitian Manajemen. Semarang: BP Undip.

Gumbira, E dan A. Haritz. 2001. Manajemen Agribisnis. PT. Ghalia Indonesia. Jakarta.

Hui C.K.P., C. Vigneault, D.I. Leblanc, J.R. Dell, and S.A. Sotocinal. 2003. Transportation and Handling of Fresh Fruits and Vegetables di dalam Chakraverty A., A.S. Mujumdar, G.S.V. Ragavan and H.S. Ramaswamy (Ed) Handbook of Postharvest Technology: Cereals, Fruits, Vegetables, Tea, and Spices. Marcel Dekker, Inc. New York.

Hult, G.T.M., D.J.K. Ketchen and M. Arrelti, 2007. Strategic supply chain management: Improving performance through a culture of competitiveness and knowledge development. Journal of Strategy Management 28, pp. 1035-1052. 